\title{
CORPORATE INVESTMENT IN THE GLOBAL FINANCIAL CRISIS
}

\author{
Michele JUCÁ (D) $1^{*}$, Albert FISHLOW (iD)2 \\ ${ }^{1}$ Social and Applied Sciences Centre, Mackenzie Presbyterian University, \\ Sao Paulo, Brazil \\ ${ }^{2}$ Institute of Latin American Studies, Columbia University, New York, \\ United States of America
}

Received 24 February 2020; accepted 15 January 2021

\begin{abstract}
This paper exams the impact of high levels of bank debt, leverage, credit obtained from government banks and cash reserves in the long and short terms investments of firms in the main Latin American countries after this crisis. For this purpose, it is applied a difference-in-differences test in a sample of more than 500 public and private firms, using hand-collected data of firms' governmental bank dependence. The review period considers five previous (2003-2007) and subsequent years (2008-2012) to the crisis. The major results are reduction of long-term investments for firms with greater banking dependence, as well as short-term investments for firms with a higher level of cash reserves. Besides, firms that are more reliant on government-owned banks reduce capital expenditures. Differently from other studies, this one examines the impact of the last global financial crisis on the firms' investment, considering its dependence of bank debt of institutions that belongs to the government or not. Understanding the mechanisms available to emerging economies can shed light on new countercyclical policies of governments and changes in the legislations of the financial system.
\end{abstract}

Keywords: financial crisis, corporate investment, bank dependence, state-owned banks, cash holding, government's countercyclical policy, differences-in-differences.

JEL Classification: G01, G21, G31, G32, C33.

\section{Introduction}

Important global financial crises took place in Latin America in the 1980s and 1990s, Asia in the late 1990s, as well as in the United States of America (USA), from subprime customers in the end of 2007. The contagion effect of this crisis affected all markets, peaking in 2012 in Europe. Unlike other crises, this one does not originate in emerging markets. Actually, the previous experience of emerging countries enabled them adopting anticyclical measures (Geyt et al., 2013; Anderson, 2019; Cortes et al., 2019).

${ }^{\star}$ Corresponding author. E-mail: michele.juca@uol.com.br

Copyright (c) 2021 The Author(s). Published by Vilnius Gediminas Technical University

This is an Open Access article distributed under the terms of the Creative Commons Attribution License (http://creativecommons. org/licenses/by/4.0/), which permits unrestricted use, distribution, and reproduction in any medium, provided the original author and source are credited. 
This crisis caused changes in the financing and investment decisions of firms. Among the theories that seek to understand these changes are those of shock in the supply of credit and demand. Firms tried to overcome both restrictions by reducing operating expenses and capital expenditures, as well as by retention of cash, highlighting the relevance of liquidity. On the banks side, poor quality assets in their portfolios limited their ability to make new loans, especially affecting firms with greater banking dependence. Faced with uncertainties, there was also a reduction in demand from customers. This set of factors ends up reducing the level of investment of firms (Campello et al., 2010; Ivashina \& Scharfstein, 2010; Kahle \& Stulz, 2013; Bo et al., 2014; Chen et al., 2020; Guevara et al., 2021).

In the corporate finance literature, there is a predominance of market imperfections that are even more evident in times of financial crisis. On this occasion, there is an intensification of informational asymmetry (Myers \& Majluf, 1984) and agency problems (Jensen \& Meckling, 1976; Khan et al., 2018) among creditors, owners and managers. This fact causes a rise in the cost of capital, making it even more difficult to finance external resources - as indicated by Myers (1984) in his pecking order theory (POT). This effect is mitigated for firms that are more liquid - with greater volume of domestic resources - or that have greater indebtedness capacity. Thus, investment decisions are unequivocally dependent on financing alternatives (Kahle \& Stulz, 2013; Bo et al., 2014; Shiau et al., 2018; Zubair et al., 2020).

Latin American countries adopted anticyclical policies to mitigate the effects of the global financial crisis and increase the level of investment by firms. In the specific case of Brazil, fiscal policy is driven more as a support to credit policy than to directly stimulate the economy. The National Treasury (NT) relocate resources to the National Bank for Economic and Social Development (BNDES). In turn, BNDES transferred these resources to firms directly or through private banks or other banks that belong to the government, such as the Bank of Brazil (BB) and Federal Savings Bank (CEF). The expansion of credit granted by governmentcontrolled banks occurs significantly, even after the recovery of the economy (Bonomo et al., 2015; Cortes et al., 2019; Bacen, 2020; Silva et al., 2020).

In view of the above, the purpose of this study is to answer the following questions related to a global financial crisis environment: a) Do demand and credit supply shocks cause a greater reduction in the investments of more leveraged or bank dependent firms? b) Do firms that receive funds from government banks have their investments less affected? and c) Firms with higher cash volume, compensate for the credit shortage and have their investments less affected? Therefore, the research problem is to analyze the impact of firms with high banking dependence, high leverage, greater reliance on government bank resources and highly liquid on their investment level in a financial crisis environment.

In order to answer those questions, it is applied a difference-in-difference (DID) test, in which the exogenous event is the international financial crisis. The sample is composed of 5,060 observations and 506 publicly traded and private firms from the main Latin American countries - Brazil, Mexico, Argentina, Colombia, Chile and Peru. The review period considers five years before (2003-2007) and after (2008-2012) the financial crisis. The relevance of the analysis of this period refers to a significant drop in gross capital formation and in the granting of credit by domestic-private banks, during and after the crisis. This fact motivated the implementation of countercyclical policies by the federal governments, such as com- 
pany financing by state-owned banks. These policies can be replicated in similar recession scenarios as this pandemic one of the new Corona Virus - SARS-CoV-2 - called Covid-19.

The studies of Duchin, Ozbas, and Sensoy (2010), Campello et al. (2012), Bo, Driver, and Lin (2014) and Shiau, Chang, and Yang (2018) analyze the impact on investment after the global financial crisis, looking at the previous levels of external and internal resources of firms. However, they do not investigate the issue of bank dependency. In turn, the surveys of Ivashina and Scharfstein (2010), Kahle and Stulz (2013), González (2016) as well as that of Adachi-Sato and Vithessonthi (2020) verify the impact of banking dependence on the post-crisis firms' investment decisions. Nevertheless, there is no decomposition of the origin of bank credit - whether governmental or not. To the best of our knowledge, there are no studies of this nature directed exclusively at Latin American countries and that consider private firms.

Thus, the novelty of this paper consists of the analysis of companies' bank dependence, as well as the impact of credit origin from governmental banks on firms' investment level in post-crisis periods. Moreover, the importance of analyzing the impact of financial crises on corporate decisions is highlighted, given the adverse consequences of unemployment, recession and other macroeconomic and microeconomic problems. In 2020, there is a possibility of a new financial crisis arises in the USA with aspects that are similar to the previous one; but perhaps more severe. Europe and Japan may have problems again.

Concerning the limitations of this study, the disclosure of capital expenditure (Capex) information in the cash flow financial statement becomes required only after the mandatory adoption of International Financial Reporting Standards (IFRS) in each country - Argentina (2012), Brazil (2010), Chile (2013), Colombia (2015), Mexico (2012) and Peru (2012). Therefore, the analysis of long-term investment considers a reduced sample of 375 firms.

Understanding the mechanisms available to emerging economies - and their heightened role in the global scenario - will shed light on possible new countercyclical policies of governments, as well as eventual changes in the rules of the financial system - eg Basel Accord, fintechs, positive register etc (Williams, 2018; Cox, 2019). On the corporate side, it is important to understand the role of cash and access to alternative sources of capital as options for not restricting their investments.

The remainder of this paper is organized as follows. Section 1 briefly describes the literature review of global financial crisis, corporate investment and the hypotheses of the study. Section 2 provides an overview of the sample, data collection, statistical tests and econometric model. Section 3 includes the results of the research. Section 4 presents a discussion and interpretation of the obtained results. Finally, last Section provides the main conclusions of this paper.

\section{Literature review}

At the end of 2007, private-domestic banks in the USA present mortgage problems with their subprime clients, originating the last global financial crisis. This crisis differs from previous ones in some aspects: a) it does not start in emerging countries, b) the significant reduction of Latin American public external debt gives governments more space to play a stabilizing 
role in private markets and (c) new types of vulnerabilities arise, mainly associated with financial innovation and integration and not with macroeconomic imbalances or banking sector deficiencies (Berger \& Roman, 2015; Wójcik \& Cojoianu, 2018).

Even though Latin America countries suffered during the last financial crisis, they have been surprisingly resilient. Brazil, Chile, Colombia, Mexico, and Peru improved their macroeconomic, financial, and regulatory policies, being more monetarily connected to other economies. Unfortunately, this improvement did not occur to Argentina.

In the case of Brazil, the government started a countercyclical policy with public banks reducing interest rates among other measures. As a result, during the pre (2005 and 2007) and post (2008 and 2011) crises, the reduction in Gross Domestic Product (GDP) in Latin America is $-1.9 \%$, while in Brazil the decrease is only $-0.3 \%$. Peru $(-1.2 \%)$, Mexico $(-1.9 \%)$, Colombia $(2.2 \%)$ and Chile $(-2.2 \%)$ are close to the regional average $(-1.9 \%)$, with a most negative impact for Argentina (-5.1\%) (World Bank, 2020a). This countercyclical policy in Brazil is effective until 2013. After 2014, there is a further fall in GDP, from $-3.77 \%$ in 2015 and $-3.36 \%$ in 2016. From this period, the government returns to insist on increasing lending through subsidized rates. In fact, the Central Bank of Brazil (Bacen) shows that credit operations with public banks grew by $16.7 \%$ between 2013 and 2014, reaching a relative participation of 53.8\% of GDP. However, the balance of private and foreign banks grows only $6.1 \%$ and $4.6 \%$, respectively (Institute of Applied Research, 2011; Paula et al., 2013; Bacen, 2014; Dieese, 2014; World Bank, 2020a)

More recently, there is fear that a new crisis may occur in the USA. Interest rates remain close to zero - as they have for almost a decade. This has caused migration of investor flows to speculative and non-traditional fixed income products. Despite the high level of corporate indebtedness, resources are not being invested in productive assets, but rather in the repurchase of shares of the firms themselves. This has increased the price of shares, and thereby the variable compensation of executives, further reducing the liquidity of these firms. Another aspect is the federal deficit of more than US\$ 1 trillion in 2018 - corresponding to 5\% of Gross Domestic Product (GDP). This may lead to an increase in the interest rate on Treasury bonds in the near future. In addition, the Federal Reserve (FED) has been conducting quantitative tightening operations aimed at reducing the monetary amounts added during quantitative easing - which began with the 2007 crisis, thereby - causing a slowdown of market liquidity (Williams, 2018; Cox, 2019).

Understanding the main theories seeking to clarify the causes and effects of the 2007 crisis contributes to better management of future crises at the corporate and macroeconomic level. Restriction of credit supply leads to bank losses on their structured operations portfolios and real estate mortgages. To reduce these assets, they sold bonds, did not renew existing loans, and did not grant new ones. As a result, firms found it more difficult to obtain credit from banks. Those who had access to other sources were less impacted than those with greater bank dependence. For them, it is more difficult and/or expensive to replace this resource. Alternative sources of credit may not have all the necessary information about these firms, thereby increasing cost of capital appropriate to their real risk. This restriction on access to credit leads to a decrease in capital expenditure investments (Brunnermeier, 2009; Chava \& Purnanandam, 2011; Carvalho et al., 2015; Fernández et al., 2018; Mercatanti et al., 2019; Guevara et al., 2021). Based on this: 
H1 - In a financial crisis environment, firms with high banking dependence have a greater reduction in investment.

The restriction in the supply of credit was not limited to the banks. Investors in general had losses when they realized that the securities purchased had a higher than expected level of risk. Thus, the market began to prioritize higher quality assets, reducing the supply of credit, making it more expensive and making it difficult for banks to acquire loans. For some firms - especially smaller ones, newer and more innovative - third-party capital not only had a cost increase but also became inaccessible. Investors can not anticipate receiving interest from high risk stocks and therefore fail to acquire them, reducing liquidity and trading volume in the primary and secondary debt securities markets. The crisis also causes a reduction in the value of firm assets, equity and collaterals. These factors force firms to reduce their capital expenditures, especially those that are more indebted (Duchin et al., 2010; Bo et al., 2014; Bonomo et al., 2015; Adachi-Sato \& Vithessonthi, 2020). Thus, it is assumed that:

$\mathrm{H} 2$ - In a financial crisis environment, firms with high leverage have a greater reduction in investment.

On the other hand, there is also a reduction in consumption and an increase in uncertainty about future demand. Among the reasons is the restriction of consumer credit. At the outset, subprime customers suffer a decline in credit and, consequently, in consumption, as a result of the loss of value of the principal asset to be pledged - their home. As a result, households reduce spending and prioritize savings. Uncertainty increases and the demand for products/services of firms decreases due to loss of consumer confidence. At that moment, the crisis previously located in the financial sector, extends systematically to the entire market. In the specific case of the Latin American countries, the fall in commodity prices and the retraction of exports are the most relevant aspects of crisis transmission (Tong \& Wei, 2008; Ocampo, 2009; Ahn et al., 2011; Kahle \& Stulz, 2013).

In order to mitigate both corporate credit constraints and reduced consumer demand, Latin American countries adopted countercyclical monetary and credit policies, made possible by larger foreign exchange reserves. Such policies facilitated export financing and rollover of corporate debts. Development and government banks have also been called on to maintain healthy growth in domestic credit. In the case of Brazil, in 2008, the government reduced compulsory deposits and lowered the basic interest rate to increase liquidity. However, the most symbolic measure was a contribution of National Treasury resources to the BNDES in 2009 of about US\$ 43 billion, passed on to other government and private banks. In fact, between 2007 and 2012, bank government loans increase from 34\% to 48\%, with a 56\% peak in 2016 (Cortes et al., 2019; Bacen, 2020; Silva et al., 2020). Having said that:

H3 - In a financial crisis environment, firms with greater reliance on government bank resources have a smaller reduction in investment.

According to Keynes (1936), there are three main reasons for cash retention by firms: a) transactional - to finance their operations, b) speculation - to enable eventual investment and c) precaution - to avoid future uncertainties that may require additional cash, thereby avoiding potential damages. Campello et al. (2012) emphasize that the reason for caution is the one that stands out most in periods of financial crisis, since the cash comes as liquidity 
insurance for crisis management. Kahle and Stulz (2013) find that during the financial crisis, firms compensate for the reduction in liquidity, caused by the shocks in the supply of credit and demand, by maintenance of their cash reserves. In normal or expansionary economic times, firms with difficulties in attracting foreign resources or with real investment options are expected to finance their operations with their cash reserves (Ramezani, 2011). However, in a financial crisis, firms assume even greater future difficulties in contracting debts; consequently, they become more conservative in the use of their cash. Those firms with high cash levels reduce their investments after the crisis. Indeed, Mercatanti, Mäkinen, and Silvestrini (2019) posit that, during the financial crisis, there is a negative relation between corporate investment and short-term debt net of cash reserve. Thus, it is noted that:

H4 - In a financial crisis environment, highly liquid firms have a greater reduction in investment.

\section{Methodology}

The sample consists of 5,060 observations and 506 firms, of which 152 are privately held and 354 are publicly traded in the main Latin American countries - Argentina (54), Brazil (162), Chile (124), Colombia (19), Mexico (67) and Peru (80). Privately held companies have similar size to publicly traded ones, meeting the criteria of total assets above US\$ 1 million. They were selected due to their growing relevance into region's economy, as well as to the increasing of the limited publicly traded companies' sample. Those countries stand out when considering their participation in the Latin American GDP - Argentina (11\%), Brazil (35\%), Chile (5\%), Colombia (5\%), Mexico (19\%), Peru (4\%) (World Bank, 2020a). The data are obtained from the Capital IQ database.

All sample companies have total assets above US\$ 1 million in 2001 and positive values in other years. Moreover, they also present positive equity in all years of the sample. Public sector firms and financial firms are excluded. Variables were winsorized between the 5 th and 95th percentile to reduce outliers' effects. Data related to government bank debt dependence is hand-collected from capital structure details of CIQ. For this, government owned banks are identified for each country.

Variables' formulas and references are presented in Appendix. The initial year of the financial crisis is 2008 - to countries other than the USA. The sample considers the five preceding (2003 to 2007) and following (2008 to 2012) years of the crisis. Moreover, a robustness test is performed for the periods 2002-2007 (pre) and 2008-2013 (post), as well as for the periods 2004-2008 (pre) and 2009-2013 (post), with an intent of finding an eventual lagged effect of the crisis on the corporate investment.

The hypotheses are tested by descriptive statistics, correlation analysis, mean difference and differences-in-differences (DID) test. This last test considers time and group dimensions to control fixed unobserved omitted variables. DID as well as fixed effects consider that omitted time-invariant variables might be used to control endogeneity problems of omitted variables. Therefore, correlation problems between explanatory variables and the error term associated with countries, industries and firms - are controlled by the consideration of fixed effects and a set of dummy variables in the regression model. Countries' characteristics at the 
previous year of the crisis (2007) are treated in the same way to soften endogeneity problems (Angrist \& Pischke, 2008; Robert \& Whited, 2013; Lee, 2016).

Equation (1) tests the hypotheses of this paper, where the dependent variable is corporate investment of long and short term - capital expenditure (Capex) and net working capital (NWC), respectively. The years after the crisis are identified with a dummy equal to one. The independent variables are from 2007 before the start of the crisis, being dependence on bank debt, leverage, government bank debt and cash reserve. They are tested in continuous form and by dummies variables. The percentages higher than the country median are classified as one. The opposite is zero. For the control variables, all of them are lagged by a year to avoid simultaneity with the corporate investment, being cash flow, size, tangibility and age. Moreover, to capture any heterogeneity resulting from omitted variables, fixed-effect dummies are included. Possible shocks in specific industries are controlled by industry-year $\left(\lambda_{j t}\right)$ effect. Eventual shocks and changes in the institutional and regulatory environment in specific countries are controlled by country-year $\left(\theta_{\mathrm{kt}}\right)$ effect. Finally, omitted variables of firms, industries and countries that do not vary in time are controlled by firm specific effect $\left(\gamma_{\mathrm{ijk}}\right)$. Standard errors are grouped by country - the observations are independent between groups of countries (clusters), but not necessarily within them. The control of specific effects of the firms that are not observed is done by these adjustments

$$
\begin{aligned}
& \text { Inv } v_{i t}=\alpha_{0}+\alpha_{1} \text { Crisis }_{k t}+\alpha_{2}\left(\text { Crisis }_{k t} \times \text { IndVar07 }_{i}\right)+ \\
& \alpha_{3} \text { Firm controls }{ }_{i t-1}+\lambda_{j t}+\theta_{k t}+\gamma_{i j k}+\mu_{i j k t} \text {, }
\end{aligned}
$$

in which: Inv - corporate investment, being long (Capex) and short (NWC) term; Crisis dummy, being 1 after (2008-2012) and 0 before the crisis (2003 and 2007); IndVar07 - independent variables at the end of 2007; Firm controls - cash flow, size, tangibility and age, $i$ - firm; $j$ - industry; $k$ - country; $t$ - year; $\lambda_{j t}$ - industry-year effect; $\theta_{k t}$ - country-year effect; $\gamma_{i j k t}$ - firm specific effects; $\mu_{i j k t t}$ - residuals.

\section{Results analysis}

Table 1 indicates that Brazil represents 32\% of the sample, while Colombia has only $3.8 \%$ of the total firms. Colombia also stands out as having the largest (lowest) level of long-term investment - CA of 5.6\% (NW of 0.2\%). Regarding banking dependence in 2007, on average, firm's banking indebtedness is of $11.7 \%$, representing about half of their total debts $(21.5 \%)$. This proportion is more distorting for firms in Colombia, whose bank debt accounts for about $83 \%$ of their total debt. Regarding the dependence on resources coming from government banks, Brazil has the highest indebtedness of firms of this type. In 2007, of the 162 firms, 120 of them (74\%) have debts with government banks. These resources represent on average $5.3 \%$ of the assets of Brazilian firms. Brazil also has the most liquid firms in the sample with an average cash reserve of $11 \%$ in 2007 . Peru has the best operating income cash flow (13.4\%) and higher asset depreciation (90.3\%). As for size, Mexico has the largest (7.05), while Colombia has the oldest firms (59.34).

Table 1 shows the average of variables for each sampled country (lines), as well as other descriptive measures for the whole sample (columns) for the total period from 2003 to 2012. 
Table 1. Descriptive statistics

\begin{tabular}{|l|c|c|c|c|c|c|c|c|c|c|c|}
\hline DES & Obs & CA & NW & BD7 & LE7 & GB7 & CR7 & CF & Size & Tang & Age \\
\hline AR & 540 & 0.04 & 0.04 & 0.10 & 0.19 & 0.00 & 0.06 & 0.12 & 5.39 & 0.81 & 47.9 \\
\hline BR & 1,62 & 0.04 & 0.04 & 0.11 & 0.23 & 0.05 & 0.11 & 0.12 & 6.50 & 0.21 & 55.3 \\
\hline $\mathrm{CH}$ & 1,24 & 0.04 & 0.03 & 0.12 & 0.23 & 0.00 & 0.06 & 0.11 & 5.65 & 0.84 & 54.2 \\
\hline $\mathrm{CO}$ & 190 & 0.05 & 0.00 & 0.13 & 0.15 & 0.00 & 0.04 & 0.07 & 6.05 & 0.64 & 59.3 \\
\hline $\mathrm{ME}$ & 670 & 0.04 & 0.02 & 0.12 & 0.20 & 0.00 & 0.08 & 0.12 & 7.05 & 0.73 & 52.2 \\
\hline $\mathrm{PE}$ & 800 & 0.04 & 0.06 & 0.10 & 0.16 & 0.00 & 0.09 & 0.13 & 4.59 & 0.90 & 41.2 \\
\hline Obs & 5,06 & 5,06 & 5,06 & 5,06 & 5,06 & 5,06 & 5,06 & 5,06 & 5,06 & 5,06 & 5,06 \\
\hline $\mathrm{MN}$ & $\mathrm{n} / \mathrm{a}$ & 0.04 & 0.04 & 0.11 & 0.21 & 0.01 & 0.08 & 0.12 & 5.92 & 0.62 & 51.7 \\
\hline $\mathrm{MD}$ & $\mathrm{n} / \mathrm{a}$ & 0.03 & 0.01 & 0.09 & 0.22 & 0.00 & 0.05 & 0.11 & 5.99 & 0.64 & 49.0 \\
\hline $\mathrm{DES}$ & $\mathrm{Obs}$ & $\mathrm{CA}$ & $\mathrm{NW}$ & $\mathrm{BD} 7$ & $\mathrm{LE7}$ & $\mathrm{GB7}$ & $\mathrm{CR7}$ & $\mathrm{CF}$ & Size & Tang & Age \\
\hline SD & $\mathrm{n} / \mathrm{a}$ & 0.04 & 0.13 & 0.11 & 0.14 & 0.04 & 0.08 & 0.08 & 1.87 & 0.53 & 32.1 \\
\hline Min & $\mathrm{n} / \mathrm{a}$ & 0 & -0.23 & 0 & 0 & 0 & 0.00 & -0.01 & 2.09 & 0 & 4 \\
\hline Max & $\mathrm{n} / \mathrm{a}$ & 0.17 & 0.34 & 0.35 & 0.49 & 0.14 & 0.28 & 0.35 & 9.66 & 1.80 & 122 \\
\hline
\end{tabular}

Notes: DES - Description; CA - Capital expenditures; NW - Net working capital; BD7 - Dependence on bank in 2007; LE7 - Leverage in 2007; GB7 - Debt dependence of government banks in 2007; CR7 Cash reserve in 2007; CF - Cash flow; Tang - Tangibility; AR - Argentina; BR - Brazil; CH - Chile; CO - Colombia; ME - Mexico; PE - Peru; MN - Mean; MD - Median; Min - Minimum; Max - Maximum; - n/a - not applicable; SD - Standard deviation; Obs - number of observations.

Table 2, as expected, shows a negative relationship between investment in long (CA) and short (NW) terms. It is also observed that the higher the level of Lev07, the lower the investments in Capex of the firm, characterizing the firms' dependence on the restriction of this resource source. We also identify a negative relationship between NW and CR7, confirming the role of cash as a liquidity insurance in the management of external difficulties. Negative relationships of NW with size and age are also identified. The other relations between the investment and explanatory variables have opposite signs to the expected ones or they do not have statistical significance. Higher and positive correlations between size and leverage are also noteworthy. This fact indicates the importance of the size of the firms in obtaining credit, signaling a lower level of risk of default. Moreover, the negative relationship between debts contracted with government banks and tangibility indicates that the existence of real state guarantees isn't a mandatory aspect for granting credit to large companies. Finally, the positive relation between leverage and cash reserve is in line with the trade-off theory (TOT).

Table 2 presents the correlation among the variables. Data are obtained from 2003 to 2012.

Table 3 presents the results of the mean difference tests of the investment level of long (Capex) and short (NWC) periods after and before the global financial crisis for the firms of each sample country (Panel A), as well as for the sub-samples of firms with high and low banking dependence, leverage, government credit dependency and liquidity in 2007 (Panel B). Panel A indicates that there is a more significant reduction of Capex (NWC) for Mexico and Peru (Argentina and Peru). In turn, Panel B shows that for companies with great banking dependency, there is a reduction (increase) in investments in Capex (NWC). An opposite 
Table 2. Test of correlation

\begin{tabular}{|c|c|c|c|c|c|c|c|c|c|c|}
\hline VAR & $\mathrm{CA}$ & NW & BD7 & LE7 & GB7 & CR7 & $\mathrm{CF}$ & Size & Tang & Age \\
\hline $\mathrm{CA}$ & 1.00 & & & & & & & & & \\
\hline NW & $\begin{array}{c}-0.02 \\
{[0.09]}\end{array}$ & 1.00 & & & & & & & & \\
\hline BD7 & $\begin{array}{c}0.11 \\
{[0.00]}\end{array}$ & $\begin{array}{c}0.00 \\
{[0.66]}\end{array}$ & 1.00 & & & & & & & \\
\hline LE7 & $\begin{array}{l}-0.03 \\
{[0.02]}\end{array}$ & $\begin{array}{l}-0.00 \\
{[0.60]}\end{array}$ & $\begin{array}{c}0.00 \\
{[0.49]}\end{array}$ & 1.00 & & & & & & \\
\hline GB7 & $\begin{array}{c}0.00 \\
{[0.74]}\end{array}$ & $\begin{array}{c}-0.01 \\
{[0.20]}\end{array}$ & $\begin{array}{c}0.04 \\
{[0.00]}\end{array}$ & $\begin{array}{c}0.10 \\
{[0.00]}\end{array}$ & 1.00 & & & & & \\
\hline CR7 & $\begin{array}{l}-0.00 \\
{[0.77]}\end{array}$ & $\begin{array}{l}-0.02 \\
{[0.07]}\end{array}$ & $\begin{array}{l}-0.00 \\
{[0.59]}\end{array}$ & $\begin{array}{l}-0.15 \\
{[0.00]}\end{array}$ & $\begin{array}{c}0.12 \\
{[0.00]}\end{array}$ & 1.00 & & & & \\
\hline $\mathrm{CF}$ & $\begin{array}{l}-0.05 \\
{[0.00]} \\
\end{array}$ & $\begin{array}{c}0.03 \\
{[0.00]} \\
\end{array}$ & $\begin{array}{l}-0.06 \\
{[0.00]} \\
\end{array}$ & $\begin{array}{c}0.08 \\
{[0.00]} \\
\end{array}$ & $\begin{array}{l}-0.00 \\
{[0.99]} \\
\end{array}$ & $\begin{array}{c}0.23 \\
{[0.00]} \\
\end{array}$ & 1.00 & & & \\
\hline Size & $\begin{array}{c}0.02 \\
{[0.04]}\end{array}$ & $\begin{array}{l}-0.08 \\
{[0.00]}\end{array}$ & $\begin{array}{c}0.02 \\
{[0.09]}\end{array}$ & $\begin{array}{c}0.32 \\
{[0.00]}\end{array}$ & $\begin{array}{c}0.17 \\
{[0.00]}\end{array}$ & $\begin{array}{c}0.09 \\
{[0.00]}\end{array}$ & $\begin{array}{c}0.16 \\
{[0.00]}\end{array}$ & 1.00 & & \\
\hline Tang & $\begin{array}{c}-0.05 \\
{[0.00]}\end{array}$ & $\begin{array}{l}-0.03 \\
{[0.00]}\end{array}$ & $\begin{array}{l}-0.02 \\
{[0.03]}\end{array}$ & $\begin{array}{c}-0.04 \\
{[0.00]}\end{array}$ & $\begin{array}{l}-0.41 \\
{[0.00]}\end{array}$ & $\begin{array}{c}-0.15 \\
{[0.00]}\end{array}$ & $\begin{array}{c}0.06 \\
{[0.00]}\end{array}$ & $\begin{array}{l}-0.09 \\
{[0.00]}\end{array}$ & 1.00 & \\
\hline Age & $\begin{array}{c}0.03 \\
{[0.01]}\end{array}$ & $\begin{array}{l}-0.04 \\
{[0.00]}\end{array}$ & $\begin{array}{c}0.03 \\
{[0.02]}\end{array}$ & $\begin{array}{l}-0.01 \\
{[0.26]}\end{array}$ & $\begin{array}{c}0.08 \\
{[0.00]}\end{array}$ & $\begin{array}{c}0.02 \\
{[0.03]}\end{array}$ & $\begin{array}{c}0.02 \\
{[0.06]}\end{array}$ & $\begin{array}{c}0.02 \\
{[0.03]}\end{array}$ & $\begin{array}{l}-0.02 \\
{[0.14]}\end{array}$ & 1.00 \\
\hline
\end{tabular}

Notes: Spearman's correlation coefficient is above, while level of significance [in brackets] is bellow; VAR - Variables; CA - Capital expenditures; NW - Net working capital; BD7 - Dependence on bank in 2007; LE7 - Leverage in 2007; GB7 - Debt dependence of government banks in 2007; CR7 - Cash reserve in 2007; CF - Cash flow; Tang - Tangibility.

Table 3. Mean difference test

\begin{tabular}{|c|c|c|}
\hline Description & $\begin{array}{c}\text { Capex } \\
\text { (POST-PRE crisis) }\end{array}$ & $\begin{array}{c}\text { NWC } \\
\text { (POST-PRE crisis) }\end{array}$ \\
\hline \multicolumn{3}{|l|}{ Panel A } \\
\hline Argentina & -0.00197 & $-0.0231^{\star *}$ \\
\hline Brazil & $-0.0031^{*}$ & $0.0074^{*}$ \\
\hline Chile & $-0.0034^{\star}$ & 0.0031 \\
\hline Colombia & -0.0012 & $-0.0169^{*}$ \\
\hline Mexico & $-0.0069^{* * *}$ & -0.0028 \\
\hline Peru & $-0.0046^{* *}$ & $-0.0136^{* *}$ \\
\hline \multicolumn{3}{|l|}{ Panel B } \\
\hline Companies with high bank dependency & $-0.0098^{\star * *}$ & $0.0056^{*}$ \\
\hline Companies with low bank dependency & $0.0020^{\star}$ & $-0.0103^{\star * *}$ \\
\hline Companies with high leverage & $-0.0024^{\star *}$ & -0.0043 \\
\hline Companies with low leverage & $-0.0050^{* * *}$ & -0.0006 \\
\hline Companies with high government bank dependency & $-0.0055^{\star * *}$ & -0.0041 \\
\hline Companies with low government bank dependency & $-0.0033^{* * *}$ & -0.0020 \\
\hline Companies with high cash reserve & $-0.0043^{\star * *}$ & -0.0027 \\
\hline Companies with low cash reserve & $-0.0032^{\star *}$ & -0.0022 \\
\hline
\end{tabular}

Notes: Capex - Capital expenditures; NWC - Net working capital; Levels of significance of $1 \%\left({ }^{* * *}\right)$, $5 \%(* *)$ and $10 \%\left({ }^{*}\right)$. 
move occurs for firms with less banking dependence. This fact suggests that, after the global financial crisis, firms with greater banking dependence direct their investments to short-term assets, to the detriment of long-term assets.

Those with less banking dependence prioritize their long-term investments. In Latin American countries, domestic credit to private sector is mainly financed by banks. Thus, only a smaller portion of the credit originates in the capital market. With the financial crisis, access to these resources has become even more restricted, especially to short-term ones. In addition, there is a reduction in long-term investments for firms with high and low dependence on third-party resources in general, indicating that this characteristic is not a discriminating factor in Capex investment of firms after the crisis. Contrary to expectations, firms with greater and less reliance on government-owned banks reduce their long-term investments. Finally, firms with high and low cash reserves also reduce their capital expenditures, suggesting a more conservative use of their cash.

Table 3 shows the paired-mean differences for companies' investment variables Capex and NWC for the previous (PRE-2003-2007) and subsequent (POST-2008-2012) periods to the global financial crisis.

Table 4 analyzes the impact of the global financial crisis on Capex through the DID approach. In addition to the independent variables of banking dependence, leverage, credit dependency of government banks and liquidity, there is a control of regressions by means of lagged standard determinants that impact the level of investment of firms. Model 1 indicates that firms in general do not reduce their level of long-term investment. However, Models 2 and 3 confirm that firms with greater bank dependence reduce their capital expenditures after the crisis, corroborating the shock theory of credit supply by banks, especially. This result is in line with the studies of Kahle and Stulz (2013) and González (2016), mean difference test of Table 3 (Panel B) and it confirms H1.

The same can't be said for firms that are more leveraged, regardless of the origin of the credit (Models 4 and 5) or for those with the highest liquidity (Models 8 and 9). Firms that have this dependency in 2007 do not reduce their long-term investments after the crisis. Finally, debt-dependent firms contracted with government banks in 2007 are no different from those that do not. Both increase their investments in Capex after the crisis. The results of independent variables (leverage, debt dependence of government banks and cash reserve) are opposite to those in Table 3 (Panel B), which does not consider control variable impacts of equation 1 on companies' long-term investment level. In fact, according to the World Bank, the gross capital formation has increased in subsequent years (2008-2012), compared to previous years (2003-2007) to the crisis for Brazil (2008-2012), Chile, Colombia, Mexico and Peru (World Bank, 2020b).

Table 4 shows DID's test results in which the explained variable is capital expenditures of the firm.

Table 5 analyzes the impact of the global financial crisis on firms' NWC through the DID approach. Unlike Capex, firms generally reduce their short-term investments after the last global financial crisis (Model 1), similar to the study by Duchin, Ozbas, and Sensoy (2010). This reduction is even more significant for firms that have debt dependence with government banks (Models 6 and 7), contrary to H3 and to Table 3 (Panel B) results. With regard 
to this type of banking dependence, Brazil stands out as the country with the highest anticyclical policy performance by granting loans to firms through its financial institutions - eg BNDES, BB and CEF. Of the 162 Brazilian firms, 120 (74\%) contracted debts with government banks in 2007. In the case of other countries, this percentage is less than $15 \%$. In the study by Bonomo, Brito, and Martins (2015), they suggest an apparent failure of this policy to foster local economies. According to the authors, credit expansion occurs mainly for well-

Table 4. Changes in investment in long term (Capex)

\begin{tabular}{|c|c|c|c|c|c|c|c|c|c|}
\hline $\begin{array}{l}\text { Variables/ } \\
\text { Models }\end{array}$ & (1) & (2) & (3) & (4) & (5) & (6) & (7) & (8) & (9) \\
\hline Crisis & $\begin{array}{c}0.028 \\
*\end{array}$ & 0.013 & $\underset{* * *}{0.080}$ & $\underset{* *}{0.023}$ & $\underset{* * *}{0.143}$ & $\underset{* * *}{0.093}$ & $\underset{* * *}{0.142}$ & $-\underset{* * *}{-0.050}$ & -0.058 \\
\hline $\begin{array}{l}\text { Crisis* } \\
\text { BDep07 }\end{array}$ & & $-\underset{* * \star}{-0.058}$ & & & & & & & \\
\hline $\begin{array}{l}\text { Crisis }^{*} \\
\text { DHBDep07 }\end{array}$ & & & $-\underset{* * \star}{0.010}$ & & & & & & \\
\hline Crisis* Lev07 & & & & 0.001 & & & & & \\
\hline $\begin{array}{l}\text { Crisis }^{\star} \\
\text { DHLev07 }\end{array}$ & & & & & 0.002 & & & & \\
\hline $\begin{array}{l}\text { Crisis* } \\
\text { GBDep07 }\end{array}$ & & & & & & 0.065 & & & \\
\hline $\begin{array}{l}\text { Crisis }^{*} \\
\text { DHGBDep07 }\end{array}$ & & & & & & & 0.001 & & \\
\hline Crisis $^{*}$ CRes07 & & & & & & & & -0.026 & \\
\hline $\begin{array}{l}\text { Crisis* } \\
\text { DHCRes07 }\end{array}$ & & & & & & & & & -0.002 \\
\hline $\mathrm{CF}_{\mathrm{t}-1}$ & -0.003 & -0.002 & -0.003 & -0.003 & -0.003 & -0.003 & -0.003 & -0.003 & -0.003 \\
\hline Size $_{\mathrm{t}-1}$ & -0.001 & 0.000 & 0.000 & -0.001 & -0.001 & -0.001 & -0.001 & -0.000 & -0.000 \\
\hline Tang $_{\mathrm{t}-1}$ & 0.002 & 0.002 & 0.002 & 0.002 & 0.002 & 0.002 & 0.002 & 0.002 & 0.002 \\
\hline Age $_{\mathrm{t}-1}$ & 0.001 & -0.002 & 0.000 & 0.001 & 0.001 & 0.001 & 0.001 & 0.000 & 0.001 \\
\hline$\lambda_{j t}$ & $\checkmark$ & $\checkmark$ & $\checkmark$ & $\checkmark$ & $\checkmark$ & $\checkmark$ & $\checkmark$ & $\checkmark$ & $\checkmark$ \\
\hline$\theta_{\mathrm{kt}}$ & $\checkmark$ & $\checkmark$ & $\checkmark$ & $\checkmark$ & $\checkmark$ & $\checkmark$ & $\checkmark$ & $\checkmark$ & $\checkmark$ \\
\hline$\gamma_{\mathrm{ijkt}}$ & $\checkmark$ & $\checkmark$ & $\checkmark$ & $\checkmark$ & $\checkmark$ & $\checkmark$ & $\checkmark$ & $\checkmark$ & $\checkmark$ \\
\hline CC (SE) & $\checkmark$ & $\checkmark$ & $\checkmark$ & $\checkmark$ & $\checkmark$ & $\checkmark$ & $\checkmark$ & $\checkmark$ & $\checkmark$ \\
\hline $\mathrm{R}^{2}$ & 0.002 & 0.002 & 0.001 & 0.038 & 0.007 & 0.009 & 0.003 & 0.001 & 0.004 \\
\hline $\mathrm{F}$ & 0.000 & 0.000 & 0.000 & 0.000 & 0.000 & 0.000 & 0.000 & 0.000 & 0.000 \\
\hline Obs & 3,750 & 3,750 & 3,750 & 3,750 & 3,750 & 3,750 & 3,750 & 3,750 & 3,750 \\
\hline
\end{tabular}

Notes: The disclosure of Capex information in the cash flow financial statement becomes required only after the mandatory adoption of International Financial Reporting Standards (IFRS) in each country Argentina (2012), Brazil (2010), Chile (2013), Colombia (2015), Mexico (2012) and Peru (2012). Due to this fact, for this analysis it is considered a reduced sample of 375 firms, whose Capex is disclosed and different from zero in every year. Levels of significance of $1 \%\left(^{* * *}\right), 5 \%\left(^{* *}\right)$ and $10 \%\left({ }^{*}\right)$; SE - standard error; Obs - Number of observations; Capex - Capital expenditures; $\lambda_{\mathrm{jt}}$ - industry-year effect; $\theta_{\mathrm{kt}}-$ country-year effect; $\gamma_{\mathrm{ijkt}}-$ firm specific effects; CC - Cluster by country. 
established firms - which had access to the private credit market. Because of the lack of a significant positive impact on their level of investment, they support the hypothesis that these firms replaced expensive debts for government-subsidized credits.

On the other hand, Model 8 indicates that firms that have more cash reserves or liquidity invest less in the short term than those that do not. This result confirms H4 and is in line with that obtained by Shiau, Chang, and Yang (2018). This indicates that firms opt to maintain their cash reserves rather than invest them, presenting a more conservative use of their cash in the face of uncertainties. In addition, it can be seen that firms which have a higher

Table 5. Changes in investment in short term (NWC)

\begin{tabular}{|c|c|c|c|c|c|c|c|c|c|}
\hline $\begin{array}{l}\text { Variables/ } \\
\text { Models }\end{array}$ & (1) & (2) & (3) & (4) & (5) & (6) & (7) & (8) & (9) \\
\hline Crisis & $-\underset{* * *}{-0.164}$ & $-\underset{* *}{-0.044}$ & $-\underset{* * *}{-0.187}$ & $-\underset{* * \star}{-0.073}$ & $-\underset{* * *}{-0.147}$ & $-\underset{* * *}{0.114}$ & $-\underset{* * \star}{-0.448}$ & $\underset{* *}{0.056}$ & $-\underset{* * *}{-0.209}$ \\
\hline $\begin{array}{l}\text { Crisis }^{*} \\
\text { BDep07 }\end{array}$ & & 0.051 & & & & & & & \\
\hline $\begin{array}{l}\text { Crisis }^{\star} \\
\text { DHBDep07 }\end{array}$ & & & 0.011 & & & & & & \\
\hline Crisis $^{\star}$ Lev07 & & & & -0.020 & & & & & \\
\hline $\begin{array}{l}\text { Crisis }^{\star} \\
\text { DHLev07 }\end{array}$ & & & & & -0.003 & & & & \\
\hline $\begin{array}{l}\text { Crisis* } \\
\text { GBDep07 }\end{array}$ & & & & & & $\underset{* \star}{-0.173}$ & & & \\
\hline $\begin{array}{l}\text { Crisis }^{*} \\
\text { DHGBDep07 }\end{array}$ & & & & & & & $\underset{* *}{-0.011}$ & & \\
\hline Crisis $^{*}$ CRes07 & & & & & & & & $-0.037^{\star}$ & \\
\hline $\begin{array}{l}\text { Crisis }^{*} \\
\text { DHCRes07 }\end{array}$ & & & & & & & & & -0.001 \\
\hline $\mathrm{CF}_{\mathrm{t}-1}$ & 0.017 & 0.016 & 0.018 & 0.017 & 0.017 & 0.019 & 0.018 & 0.017 & 0.017 \\
\hline Size $_{t-1}$ & $-\underset{* * *}{0.012}$ & $-\underset{* * *}{0.012}$ & $-\underset{* * *}{-0.013}$ & $-\underset{* * *}{-0.012}$ & $-\underset{* * *}{-0.012}$ & $-\underset{* * *}{0.012}$ & $-\underset{* * *}{0.012}$ & $\underset{\star * *}{-0.012}$ & $-\underset{* * *}{-0.012}$ \\
\hline Tang $_{\mathrm{t}-1}$ & -0.003 & -0.003 & -0.003 & -0.003 & -0.003 & -0.003 & -0.003 & -0.003 & -0.003 \\
\hline $\mathrm{Age}_{\mathrm{t}-1}$ & $-\underset{* * *}{-0.052}$ & $-\underset{* * *}{-0.050}$ & $\underset{* * *}{-0.051}$ & $-\underset{* * *}{-0.052}$ & $-\underset{* * *}{-0.052}$ & $-\underset{* * *}{0.053}$ & $-\underset{* * *}{-0.053}$ & $\underset{* * *}{-0.053}$ & -0.052 \\
\hline$\lambda_{\mathrm{jt}}$ & $\checkmark$ & $\checkmark$ & $\checkmark$ & $\checkmark$ & $\checkmark$ & $\checkmark$ & $\checkmark$ & $\checkmark$ & $\checkmark$ \\
\hline$\theta_{\mathrm{kt}}$ & $\checkmark$ & $\checkmark$ & $\checkmark$ & $\checkmark$ & $\checkmark$ & $\checkmark$ & $\checkmark$ & $\checkmark$ & $\checkmark$ \\
\hline$\gamma_{\mathrm{ijkt}}$ & $\checkmark$ & $\checkmark$ & $\checkmark$ & $\checkmark$ & $\checkmark$ & $\checkmark$ & $\checkmark$ & $\checkmark$ & $\checkmark$ \\
\hline CC (SE) & $\checkmark$ & $\checkmark$ & $\checkmark$ & $\checkmark$ & $\checkmark$ & $\checkmark$ & $\checkmark$ & $\checkmark$ & $\checkmark$ \\
\hline $\mathrm{R}^{2}$ & 0.000 & 0.002 & 0.002 & 0.001 & 0.000 & 0.001 & 0.001 & 0.012 & 0.006 \\
\hline $\mathrm{F}$ & 0.000 & 0.000 & 0.000 & 0.000 & 0.000 & 0.000 & 0.000 & 0.000 & 0.000 \\
\hline \# Observations & 5,060 & 5,060 & 5,060 & 5,060 & 5,060 & 5,060 & 5,060 & 5,060 & 5,060 \\
\hline
\end{tabular}

Notes: Levels of significance of $1 \%\left(^{* *}\right), 5 \%\left(^{* *}\right)$ and $10 \%\left(^{*}\right)$; SE - standard error; NWC - Net working capital; $\lambda_{\text {jt }}$ - industry-year effect; $\theta_{\mathrm{kt}}$ - country-year effect; $\gamma_{\mathrm{ijkt}}$ - firm specific effects; CC - Cluster by country. 
bank dependency (Models 2 and 3) and are more leveraged (Models 4 and 5) do not reduce their short-term investments more significantly than those that do not. This result suggests that resources for investment in net current assets do not necessarily originate from these sources, and may derive from operating liabilities or equity. We also highlight the negative and significant relationship between size and age with the level of short-term investment of firms. Shiau, Chang, and Yang (2018) identified the same negative relationship between size and net working capital investment for Chinese firms after the last global financial crisis. Finally, the negative relation between age and investment supports the theory of the life cycle of firms. The approach of firms to their more mature stage causes them to have less investment opportunities, especially in times of financial crisis.

Table 5 shows DID's test results in which the explained variable is net working capital of the firm.

Finally, Table 6 shows the test of robustness for Eq. (1). In the case of Models 1 to 4, there is confirmation of the reduction of long-term investment in Capex for firms with high banking dependence in 2007. In Model 1, this result remains, even after the exclusion of the country-year dummy variable that aims to avoid an eventual correlation with crisis variable. In Models 2, 3 and 4, the relationship remains negative and significant when the standard errors are not clustered by country or when different periods are considered, in order to better capture any delayed changes in the firms' investments. This result ratifies $\mathrm{H} 1$. In the case of Models 5 to 8, the reduction of short-term NWC investment is confirmed for firms that have greater dependence on loans granted by government banks in 2007. This result is in opposition to H3. Finally, in Models 4 and 8, the reduction in investments in Capex and NWC is highlighted, when the effect of the beginning of the crisis in 2009 is considered to be out of date. According to the World Bank (2020b), in this year, there is an average reduction of $15 \%$ in the annual growth of gross capital formation in the sample countries compared to 2008.

Table 6 presents the robustness test results in four alternative scenarios.

Table 6. Tests of robustness on investment changes after the financial crisis

\begin{tabular}{|c|c|c|c|c|c|c|c|c|}
\hline \multirow{3}{*}{ Variables } & \multicolumn{4}{|c|}{ Capital Expenditure (Capex) } & \multicolumn{4}{|c|}{ Net Working Capital (NWC) } \\
\hline & A & B & $\mathrm{C}$ & $\mathrm{D}$ & A & B & $\mathrm{C}$ & $\mathrm{D}$ \\
\hline & (1) & (2) & (3) & (4) & (5) & (6) & (7) & (8) \\
\hline Crisis & $\underset{* * *}{0.051}$ & 0.009 & $\underset{* * \star}{0.139}$ & $-\underset{* *}{0.023}$ & $\underset{* * *}{0.153}$ & 0.018 & $\underset{* * *}{0.513}$ & $\underset{* \star \star}{-0.080}$ \\
\hline Crisis $^{\star}$ BDep07 & $-\underset{* * *}{0.056}$ & $-\underset{* * *}{0.057}$ & $-\underset{* * *}{0.055}$ & $-\underset{* * *}{0.074}$ & 0.053 & $\underset{* *}{0.050}$ & 0.034 & $0.050^{*}$ \\
\hline Crisis* Lev07 $^{*}$ & -0.005 & -0.006 & -0.009 & 0.002 & -0.012 & $-0.028^{\star}$ & -0.034 & $-0.055^{\star}$ \\
\hline $\begin{array}{l}\text { Crisis }^{*} \\
\text { GBDep07 }\end{array}$ & 0.003 & -0.003 & -0.008 & $0.011^{\star}$ & 0.018 & $\underset{* * *}{-0.181}$ & $-0.185^{\star *}$ & $-0.132^{\star}$ \\
\hline Crisis $^{*}$ CRes07 & -0.021 & $-0.019^{*}$ & -0.018 & -0.006 & -0.024 & $-0.047^{\star}$ & -0.039 & -0.047 \\
\hline $\mathrm{CF}_{\mathrm{t}-1}$ & -0.003 & -0.000 & 0.005 & 0.001 & 0.006 & 0.019 & 0.0231 & 0.028 \\
\hline Size $_{t-1}$ & 0.000 & 0.000 & 0.000 & 0.001 & $\underset{*}{-0.006}$ & $-\underset{* * \star}{-0.011}$ & $-\underset{* * *}{0.008}$ & $-0.009^{\star}$ \\
\hline
\end{tabular}


End of Table 6

\begin{tabular}{|c|c|c|c|c|c|c|c|c|}
\hline Variables & (1) & (2) & (3) & (4) & (5) & (6) & (7) & (8) \\
\hline Tang $_{t-1}$ & 0.001 & 0.001 & 0.000 & 0.000 & -0.001 & -0.002 & -0.003 & -0.003 \\
\hline Age $_{t-1}$ & 0.001 & 0.002 & -0.002 & -0.001 & -0.053 & -0.051 & $-\underset{* * \star}{-0.037}$ & -0.030 \\
\hline$\lambda_{\mathrm{jt}}$ & $\checkmark$ & $\checkmark$ & $\checkmark$ & $\checkmark$ & $\checkmark$ & $\checkmark$ & $\checkmark$ & $\checkmark$ \\
\hline$\theta_{\mathrm{kt}}$ & $\checkmark$ & $\checkmark$ & $\checkmark$ & $\checkmark$ & $\checkmark$ & $\checkmark$ & $\checkmark$ & $\checkmark$ \\
\hline$\gamma_{\mathrm{ijkt}}$ & $\checkmark$ & $\checkmark$ & $\checkmark$ & $\checkmark$ & $\checkmark$ & $\checkmark$ & $\checkmark$ & $\checkmark$ \\
\hline CC (SE) & $\checkmark$ & $\checkmark$ & $\checkmark$ & $\checkmark$ & $\checkmark$ & $\checkmark$ & $\checkmark$ & $\checkmark$ \\
\hline $\mathrm{R}^{2}$ & 0.004 & 0.045 & 0.001 & 0.002 & 0.022 & 0.027 & 0.000 & 0.005 \\
\hline $\mathrm{F}$ & 0.000 & 0.000 & 0.000 & 0.000 & 0.000 & 0.000 & 0.000 & 0.000 \\
\hline \# Obs & 5,060 & 5,060 & 6,072 & 5,060 & 5,060 & 5,060 & 6,072 & 5,060 \\
\hline
\end{tabular}

Notes: A - Without country-year fixed effect; B - Without SE clustered by country; C - Crisis period 2008-2013; D - Crisis period 2009-2013; Levels of significance of $1 \%\left({ }^{* * *}\right), 5 \%\left({ }^{* *}\right)$ and $10 \%\left({ }^{*}\right)$; SE standard error; Capex - Capital expenditures; NWC - Net working capital; $\lambda_{\mathrm{jt}}$ - industry-year effect; $\theta_{\mathrm{kt}}-$ country-year effect; $\gamma_{\mathrm{ijkt}}-$ firm specific effects; CC - Cluster by country.

\section{Discussion and interpretation of results}

Similar to the studies by Kahle and Stulz (2013) and González (2016), H1 is confirmed. The global financial crisis caused losses to banks that compromised their ability to offer new loans to firms. Those that had mainly bank financing suffered from this credit restriction, reducing their long-term investments (Capex). The impact on reducing the creditworthiness of firms most dependent on bank loans, as confirmed by Brunnermeier (2009), Shleifer and Vishny (2010) and Berg and Gider (2017), is also verified. Here, there is no such reduction for short-term investments (NWC). This result suggests that resources for investment in net current assets do not necessarily originate from these sources.

Obviously, the credit constraint was not limited to banks. In developed countries, the uncertainty provoked by the crisis caused the market to acquire debt securities of firms with lower risk levels, restricting credit especially to smaller, younger and innovative ones. In addition, the crisis causes a devaluation of assets, reducing their net equity and collaterals, making it difficult to raise debts and realize investments. Thus, $\mathrm{H} 2$ is not confirmed in this study. In the case of the Latin American countries, firms replaced bank by non-bank debts, ratifying the fundamental role of the public credit market (eg debentures, global notes, etc.) and private sources (loans from subsidiaries/affiliates, export credit) as alternatives to third-party resources. This may have contributed to the non-reduction of investment by the most leveraged firms.

In addition to the restriction of credit to firms and consumers, there is a contraction in demand, given uncertainty of the future. For Latin American countries, the contagion effect of the crisis is mainly due to the fall in the price of commodities and the decline in exports. In order to mitigate the effects of credit shocks and demand, local governments implement counter-cyclical monetary and credit measures, made possible by their foreign exchange reserves, which facilitate export financing, corporate debt rollover and domestic credit. An example of such policies is the BNDES' activity in Brazil, which transferred funds raised from 
the National Treasury to public and private commercial banks. This leads us to H3. However, there is an opposite relationship, with the reduction of short-term investment (NWC). In the case of long-term investments (Capex), the firms with the highest dependence on loans from government banks behave the same as those without this dependence. According to Bonomo, Brito, and Martins (2015), there is controversy about the effectiveness of this policy, since the credits were granted to firms already in the market. Because of the lack of a significant positive impact on their level of investment in Capex, the authors understand that these firms have replaced expensive debt by government-subsidized credit. Considering the occurrence of this substitution, it happened in long-term, since the results point to maintenance of same levels of long-term investment and a reduction in short ones.

It is also noted the conservative role of firms' cash reserves in times of crisis to cope with the economic oscillations in the short and medium term. Cash is an alternative source of financing, given the liquidity constraints of the market, being preserved to avoid unforeseen situations. This fact raises $\mathrm{H} 4$, which is confirmed for short-term investments (NWC), similar to the study of Shiau, Chang, and Yang (2018). In the case of long-term investment (Capex), firms with high cash reserves in 2007 are not distinguished from others. In fact, according to the World Bank, gross capital formation increased in following years (2008-2012), compared to previous crisis years (2003-2007) for Brazil, Chile, Colombia, Mexico and Peru (World Bank, 2020c).

\section{Conclusions}

Unlike recent global financial crises, the one beginning in 2007 does not originate in emerging countries, but in the USA. The credit and demand shocks' offerings impact both the financing decisions and the investment decisions of the firms. To mitigate these effects, Latin American countries adopt anticyclical policies to provide credit to the market. In the case of Brazil, for example, the role of BNDES and other public banks in the granting of resources to firms stands out.

Thus, this study aims to exam the relation among high levels of bank debt, leverage, debt contracted with government banks and cash reserve, and the level of long and short-term investment of firms. The hypotheses related to this aim are: H1 - In a financial crisis environment, firms with high banking dependence have a greater reduction in investment; H2 - In a financial crisis environment, firms with high leverage have a greater reduction in investment; H3 - In a financial crisis environment, firms with greater reliance on government bank resources have a smaller reduction in investment and $\mathrm{H} 4$ - In a financial crisis environment, highly liquid firms have a greater reduction in investment.

The study points that firms that have greater dependence on banks in 2007 reduce their capital expenditures after the crisis, confirming H1. Besides, firms that have more cash reserves in 2007 invest less in the short term than those that do not, confirming H4. On the other hand, $\mathrm{H} 2$ is not confirmed. The replacement of bank by non-bank debts may have contributed to the non-reduction of investment by the most leveraged firms. Finally, firms with greater reliance on credit from government banks reduce their short-term investments, contrary to $\mathrm{H} 3$. 
It is also important to mention that data collection of Capex has a limitation. The disclosure of Capex information in the cash flow financial statement becomes required only after the mandatory adoption of International Financial Reporting Standards (IFRS) in each country - Argentina (2012), Brazil (2010), Chile (2013), Colombia (2015), Mexico and (2012). Therefore, the analysis of long-term investment considers a reduced sample of 375 firms.

The results presented in this study contribute to better understanding the impact of the last global financial crisis on the investment decisions of firms in the main Latin American countries. Understanding the mechanisms available to emerging economies - and their role in the global scenario - can shed light on possible new countercyclical policies of governments, as well as possible changes in rules of international financial system. As for firms, it is up to them to appreciate the role of cash and access to alternative sources of capital as options for not restricting their investments. Moreover, this paper findings' point to future analysis such as: a) What has been learned about the causes of the last financial crisis to prevent new ones? b) How companies can overcome problems of raising funds for the maintenance of their investments? c) What public policies should be adopted to enable a better regulatory environment for market development?

\section{Funding}

This work was supported by the $<$ National Council for Scientific and Technological Development $>$ under Grant [404250/2016-5].

\section{Author contributions}

MJ conceived the study and was responsible for the design, development of the data analysis and data collection. AF was responsible for data interpretation and wrote the drafts of the article.

\section{Disclosure statement}

The authors declare that they did not have any competing financial, professional, or personal interests from other parties.

\section{References}

Adachi-Sato, M., \& Vithessonthi, C. (2020). Bank risk-taking and corporate investment: Evidence from the global financial crisis of 2007-2009. Global Finance Journal, 100573 (in Press). https://doi.org/10.1016/j.gf.2020.100573

Ahn, J., Amiti, M., \& Weinstein, D. E. (2011). Trade finance and the great trade collapse. American Economic Review, 101(3), 298-302. https://doi.org/10.1257/aer.101.3.298

Anderson, S. (2019). A history of the past 40 years in financial crises. International Financing Review, 2000 issue supplement.

http://www.ifre.com/a-history-of-the-past-40-years-in-financial-crises/21102949.fullarticle 
Angrist, J., \& Pischke, J. S. (2008). Mostly harmless econometrics. Princeton University Press. https://doi.org/10.2307/j.ctvcm4j72

Bacen - Banco Central do Brasil. (2014). Bank economy and credit report of 2014. https://www.bcb.gov.br/publicacoes/relatorioeconomiabancaria/11122014

Bacen - Central Bank of Brazil. (2020). Time series management system. Credit indicators. Balances by capital control. Balances under public control - Total.

Berg, T., \& Gider, J. (2017). What explains the difference in leverage between banks and nonbanks? Journal of Financial and Quantitative Analysis, 52(6), 2677-2702. https://doi.org/10.1017/S0022109017000734

Berger, A. N., \& Roman, R. A. (2015). Did TARP banks get competitive advantages? Journal of Financial and Quantitative Analysis, 50(6), 1199-1236. https://doi.org/10.1017/S0022109015000630

Bo, H., Driver, C., \& Lin, H.-C. M. (2014). Corporate investment during the financial crisis: Evidence from China. International Review of Financial Analysis, 35, 1-12. https://doi.org/10.1016/j.irfa.2014.07.002

Bonomo, M., Brito, R. D., \& Martins, B. (2015). The after crisis government-driven credit expansion in Brazil: A firm level analysis. Journal of International Money and Finance, 55, 111-134. https://doi.org/10.1016/j.jimonfin.2015.02.017

Brunnermeier, M. K. (2009). Deciphering the liquidity and credit crunch 2007-2008. Journal of Economic Perspectives, 23(1), 77-100. https://doi.org/10.1257/jep.23.1.77

Campello, M., Giambona, E., Graham, J. R., \& Harvey, C. R. (2012). Access to liquidity and corporate investment in Europe during the financial crisis. Review of Finance, 16(2), 323-346. https://doi.org/10.1093/rof/rfr030

Campello, M., Graham, J. R., \& Harvey, C. R. (2010). The real effects of financial constraints: Evidence from a financial crisis. Journal of Financial Economics, 97(3), 470-487. https://doi.org/10.1016/j.jineco.2010.02.009

Carvalho, D., Ferreira, M. A., \& Matos, P. (2015). Lending relationships and the effect of bank distress: Evidence from the 2007-2009 financial crisis. Journal of Financial and Quantitative Analysis, 50(6), 1165-1197. https://doi.org/10.1017/S0022109015000551

Chava, S., \& Purnanandam, A. (2011). The effect of banking crisis on bank-dependent borrowers. Journal of Financial Economics, 99(1), 116-135. https://doi.org/10.1016/j.jfineco.2010.08.006

Chen, X., Le, C. H. A., Shan, Y., \& Taylor, S. (2020). Australian policy uncertainty and corporate investment. Pacific-Basin Finance Journal, 61, 101341. https://doi.org/10.1016/j.pacfin.2020.101341

Cortes, G. S., Silva, T., \& Van Doornik, B. F. N. (2019). Credit shock propagation in firm networks: Evidence from government bank credit expansions (BCB Working Paper no. 507). Central Bank of Brazil. https://econpapers.repec.org/paper/bcbwpaper/507.htm

Cox, J. (2019). Global debt is up 50\% over the past decade, but S\&P still says next crisis won't be as bad. CNBC. www.cnbc.com/2019/03/12/global-debt-up-50-percent-since-the-financial-crisis-sp-says.html

Dieese - Intersindical Department of Statistics and Socioeconomic Studies. (2014). O Mercado de Trabalho Formal Brasileiro: Resultados da RAIS 2013 [The Brazilian formal labor market: RAIS results 2013]. No. 140. https://www.dieese.org.br/notatecnica/2014/notaTec140Rais2013.pdf

Duchin, R., Ozbas, O., \& Sensoy, B. A. (2010). Costly external finance, corporate investment, and the subprime mortgage credit crisis. Journal of Financial Economics, 97(3), 418-435. https://doi.org/10.1016/j.jineco.2009.12.008

Fernández, A. I., González, F., \& Suárez, N. (2018). Bank supply shocks and the substitution between bank and nonbank debt. Journal of Corporate Finance, 48, 122-147.

https://doi.org/10.1016/j.jcorpfin.2017.10.010 
Geyt, D. V, Cauwenberge, P. V., \& Bauwhede, H. V. (2013). The impact of the financial crisis on insider trading profitability in Belgium. Journal of Business Economics and Management, 14(2), 364-385. https://doi.org/10.3846/16111699.2011.652980

González, F. (2016). Creditor rights, bank competition, and corporate investment during the global financial crisis. Journal of Corporate Finance, 37, 249-270. https://doi.org/10.1016/j.jcorpfin.2016.01.001

Guevara, J. F., Maudos, J., \& Salvador, C. (2021). Effects of the degree of financial constraint and excessive indebtedness on firms' investment decisions. Journal of International Money and Finance, 110, 102288. https://doi.org/10.1016/j.jimonfin.2020.102288

Institute of Applied Research. (2011). The role of federal public banks in the Brazilian economy, no. 1604. Text for discussion.

http://www.ipea.gov.br/portal/index.php?option=com_content\&view=article\&id=8058

Ivashina, V., \& Scharfstein, D. (2010). Bank lending during the financial crisis of 2008. Journal of Financial Economics, 97(3), 319-338. https://doi.org/10.1016/j.jineco.2009.12.001

Jensen, M. C., \& Meckling, W. H. (1976). Theory of the firm: Managerial behavior, agency costs and ownership structure. Journal of Financial Economics, 3(4), 305-360. https://doi.org/10.1016/0304-405X(76)90026-X

Kahle, K. M., \& Stulz, R. M. (2013). Access to capital, investment, and the financial crisis. Journal of Financial Economics, 110(2), 280-299. https://doi.org/10.1016/j.jineco.2013.02.014

Keynes, J. M (1936). The general theory of employment, interest and money. Harcourt, Brace \& World. https://doi.org/10.1007/978-3-319-70344-2

Khan, M. K., He, Y., Kaleem, A., Akram, U., \& Hussain, Z. (2018). Remedial role of financial development in corporate investment amid financing constraints and agency costs. Journal of Business Economics and Management, 19(1), 176-191. https://doi.org/10.3846/16111699.2017.1422797

Lee, M.-J. (2016). Matching, regression discontinuity, difference in differences, and beyond. Oxford University Press. https://doi.org/10.1093/acprof:oso/9780190258733.001.0001

Mercatanti, A., Mäkinen, T., \& Silvestrini, A. (2019). The role of financial factors for European corporate investment. Journal of International Money and Finance, 96, 246-258. https://doi.org/10.1016/j.jimonfin.2019.05.006

Myers, S. C. (1984). The capital structure puzzle. Journal of Finance, 39(3), 575-592. https://doi.org/10.1111/j.1540-6261.1984.tb03646.x

Myers, S. C., \& Majluf, N. S. (1984). Corporate financing and investment decisions when firms have information that investors do not have. Journal of Financial Economics, 13(2), 187-221. https://doi.org/10.1016/0304-405X(84)90023-0

Ocampo, J. A. (2009). Latin America and the global financial crisis. Cambridge Journal of Economics, 33(4), 703-724. https://doi.org/10.1093/cje/bep030

Paula, L. F., Oreiro, J. L., \& Basilio, F. A. C. (2013). Banking sector structure and the recent credit expansion cycle: The role of federal public banks. Nova Economia, 23(3), 473-520. https://doi.org/10.1590/S0103-63512013000300001

Ramezani, C. A. (2011). Financial constraints, real options and corporate cash holdings. Managerial Finance, 37(12), 1137-1160. https://doi.org/10.1108/03074351111175074

Roberts, M. R., \& Whited, T. M. (2013). Endogeneity in empirical corporate finance. In Handbook of the economics of finance (pp. 493-572). Elsevier. https://doi.org/10.1016/B978-0-44-453594-8.00007-0

Shiau, H.-L., Chang, Y.-H., \& Yang, Y.-J. (2018). The cash holdings and corporate investment surrounding financial crisis: The cases of China and Taiwan. The Chinese Economy, 51(2), 175-207. https://doi.org/10.1080/10971475.2018.1447833 
Shleifer, A., \& Vishny, R. (2010). Unstable banking. Journal of Financial Economics, 97(3), 306-318. https://doi.org/10.1016/j.jineco.2009.10.007

Silva, T. C., Tabak, B. M., \& Laiz, M. (2020). The finance-growth nexus: The role of banks. Economic Systems, 100762 (in Press). https://doi.org/10.1016/j.ecosys.2020.100762

Tong, H., \& Wei, S. (2008). Real effects of the subprime mortgage crisis: Is it a demand or a finance shock? (International Monetary Fund Working Paper 186). International Monetary Fund. https://doi.org/10.5089/9781451870442.001

Tsuruta, D. (2019). Working capital management during the global financial crisis: Evidence from Japan. Japan \& The World Economy, 49, 206-219. https://doi.org/10.1016/j.japwor.2019.01.002

Williams, A. (2018, December 10). Are you ready for the financial crisis of 2019? New York Times. https://www.nytimes.com/2018/12/10/style/2019-financial-crisis.html

Wójcik, D., \& Cojoianu, T. F. (2018). Resilience of the US securities industry to the global financial crisis. Geoforum, 91, 182-194. https://doi.org/10.1016/j.geoforum.2018.02.035

World Bank. (2020a). GDP growth (annual \%). DataBank. World Development Indicators. https://databank.worldbank.org/data/reports.aspx?source=world-development-indicators\#

World Bank. (2020b). Gross capital formation (annual \% growth). DataBank. World Development Indicators. https://databank.worldbank.org/data/reports.aspx?source=world-development-indicators\#

World Bank. (2020c). Gross capital formation (\% of GDP). DataBank. World Development Indicators. https://databank.worldbank.org/data/reports.aspx?source=world-development-indicators\#

Zubair, S., Kabir, R., \& Huang, X. (2020). Does the financial crisis change the effect of financing on investment? Evidence from private SMEs. Journal of Business Research, 110, 456-463.

https://doi.org/10.1016/j.jbusres.2020.01.063

\section{APPENDIX}

Description of variables

\begin{tabular}{|c|c|c|c|c|}
\hline Initial & ES & Name & Formula & References \\
\hline \multicolumn{5}{|c|}{ Dependent variables } \\
\hline Capex & $\mathrm{n} / \mathrm{a}$ & $\begin{array}{l}\text { Capital } \\
\text { expenditures }\end{array}$ & $\begin{array}{l}\text { Capex }=\text { Capital } \\
\text { expenditures / Total assets }\end{array}$ & $\begin{array}{l}\text { Duchin et al. (2010); } \\
\text { Mercatanti et al. (2019); } \\
\text { Adachi-Sato and } \\
\text { Vithessonthi (2020); Chen } \\
\text { et al. (2020); Zubair et al. } \\
\text { (2020) }\end{array}$ \\
\hline NWC & $\mathrm{n} / \mathrm{a}$ & $\begin{array}{l}\text { Net working } \\
\text { capital }\end{array}$ & $\begin{array}{l}\text { NWC }=\text { (Current assets - } \\
\text { Current liabilities - Cash } \\
\text { - Short-term investments) } \\
\text { / Total assets }\end{array}$ & $\begin{array}{l}\text { Duchin et al. (2010); Shiau } \\
\text { et al. (2018); Tsuruta (2019) }\end{array}$ \\
\hline \multicolumn{5}{|c|}{ Financial crisis } \\
\hline Crisis & - & $\begin{array}{l}\text { Global financial } \\
\text { crisis }\end{array}$ & $\begin{array}{l}\text { Crisis }=1 \text { if between } 2008- \\
2012 \text { and } 0 \text { if between } \\
2003-2007\end{array}$ & $\begin{array}{l}\text { Fernández et al. (2018); } \\
\text { Silva et al. (2020); Zubair } \\
\text { et al. (2020) }\end{array}$ \\
\hline \multicolumn{5}{|c|}{ Independent variables } \\
\hline BDep07 & - & $\begin{array}{l}\text { Dependence on } \\
\text { bank debt in } \\
2007\end{array}$ & $\begin{array}{l}\text { BDep07 = Bank debt / } \\
\text { Total assets }\end{array}$ & $\begin{array}{l}\text { Fernández et al. (2018); } \\
\text { Zubair et al. (2020) }\end{array}$ \\
\hline
\end{tabular}


Description of variables (continuation)

\begin{tabular}{|c|c|c|c|c|}
\hline Initial & ES & Name & Formula & References \\
\hline DHBDep07 & - & $\begin{array}{l}\text { Dummy of high } \\
\text { bank debt in } \\
2007\end{array}$ & $\begin{array}{l}\text { DHBDep07 = } 1 \text { if the value } \\
\text { exceeds the median of } \\
\text { country firms' bank debt } \\
\text { in } 2007 \text { and } 0 \text { if it is the } \\
\text { opposite }\end{array}$ & Fernández et al. (2018) \\
\hline Lev07 & - & Leverage in 2007 & $\begin{array}{l}\text { Lev07 = Total debts } / \text { Total } \\
\text { assets }\end{array}$ & $\begin{array}{l}\text { Duchin et al. (2010); Shiau } \\
\text { et al. (2018); Adachi-Sato } \\
\text { and Vithessonthi (2020); } \\
\text { Guevara et al. (2021) }\end{array}$ \\
\hline DHLev07 & - & $\begin{array}{l}\text { Dummy of high } \\
\text { leverage in } 2007\end{array}$ & $\begin{array}{l}\text { DHLev07 = } 1 \text { if the value } \\
\text { exceeds the median of } \\
\text { country firms' financial } \\
\text { leverage in } 2007 \text { and } 0 \text { if it } \\
\text { is the opposite }\end{array}$ & $\begin{array}{l}\text { Chava and Purnanandam } \\
\text { (2011); Kahle and Stulz } \\
\text { (2013); González (2016) }\end{array}$ \\
\hline GBDep07 & + & $\begin{array}{l}\text { Debt } \\
\text { dependence of } \\
\text { government } \\
\text { banks in } 2007\end{array}$ & $\begin{array}{l}\text { GBDep07 = Government } \\
\text { banks debt / Total assets }\end{array}$ & $\begin{array}{l}\text { Bonomo et al. (2015); Silva } \\
\text { et al. (2020) }\end{array}$ \\
\hline DHGBDep07 & + & $\begin{array}{l}\text { Dummy of high } \\
\text { debt dependency } \\
\text { of government } \\
\text { banks in } 2007\end{array}$ & $\begin{array}{l}\text { DHGBDep07 = } 1 \text { if } \\
\text { the value exceeds the } \\
\text { median of country firms' } \\
\text { government banks debt } \\
\text { in } 2007 \text { and } 0 \text { if it is the } \\
\text { opposite }\end{array}$ & $\begin{array}{l}\text { Bonomo et al. (2015); Silva } \\
\text { et al. (2020) }\end{array}$ \\
\hline CRes07 & - & $\begin{array}{l}\text { Cash reserve in } \\
2007\end{array}$ & $\begin{array}{l}\text { Res07 = (Cash }+ \text { Short- } \\
\text { term investments }) / \text { Total } \\
\text { assets }\end{array}$ & $\begin{array}{l}\text { Duchin et al. (2010); Shiau } \\
\text { et al. (2018); Mercatanti } \\
\text { et al. (2019); Adachi-Sato } \\
\text { and Vithessonthi (2020) }\end{array}$ \\
\hline DHCRes07 & - & $\begin{array}{l}\text { Dummy of high } \\
\text { cash reserve in } \\
2007\end{array}$ & $\begin{array}{l}\text { DHCRes } 07=1 \text { if the value } \\
\text { exceeds the median of } \\
\text { country firms' cash reserve } \\
\text { in } 2007 \text { and } 0 \text { if it is the } \\
\text { opposite }\end{array}$ & $\begin{array}{l}\text { Campello et al. (2012); } \\
\text { González (2016) }\end{array}$ \\
\hline \multicolumn{5}{|c|}{ Control variables } \\
\hline $\mathrm{CF}$ & + & Cash flow & $\mathrm{CF}=$ Ebitda $/$ Total assets & $\begin{array}{l}\text { Duchin et al. (2010); Shiau } \\
\text { et al. (2018); Mercatanti } \\
\text { et al. (2019); Zubair et al. } \\
\text { (2020) }\end{array}$ \\
\hline Size & $\begin{array}{l}+ \\
\text { or }-\end{array}$ & Size & Size $=$ Ln (Total assets) & $\begin{array}{l}\text { Duchin et al. (2010); Shiau } \\
\text { et al. (2018); Guevara et al. } \\
\text { (2021) }\end{array}$ \\
\hline Tang & + & Tangibility & $\begin{array}{l}\text { Tang = Gross property, } \\
\text { plant \& equipment / Total } \\
\text { assets }\end{array}$ & Cortes et al. (2019) \\
\hline Age & - & Age & $\begin{array}{l}\text { Ln }(\text { Age }) \text {, in which age }= \\
\text { reference year - foundation } \\
\text { year }\end{array}$ & $\begin{array}{l}\text { Bonomo et al. (2015); } \\
\text { Cortes et al. (2019) }\end{array}$ \\
\hline
\end{tabular}

Notes: n/a - not applicable; ES - expected signal. 